\title{
THE INFLUENCE OF THE CULTURE OF THE ORGANIZATION, ORGANIZATION COMMITMENT AND ACCOUNTABILITY TOWARDS THE PUBLIC HOSPITAL PERFORMANCE (RSUD) LUBUK BASUNG
}

\author{
Jolianis \\ Dosen Program Studi Pendidikan Ekonomi STKIP- PGRI Sumbar \\ Jl. Gunung Pangilun No.1, Padang Sumatera Barat \\ email : jolianiskoto@ymail.com \\ Dina Amaluis \\ Dosen Program Studi Pendidikan Ekonomi STKIP- PGRI Sumbar \\ Jl. Gunung Pangilun No.1, Padang Sumatera Barat \\ email : dinaamaluis@gmail.com \\ submitted: 2015.07.31 reviewed: 2015.12.05 accepted: 2016.06.16 \\ http://dx.doi.org/10.22202/economica.2015.v4.i1.267
}

\begin{abstract}
This research aims to analyze: 1) the influence of organizational culture on performance of hospitals, 2) The Influence of organization commitment on hospitals performance, 3) Influence on performance accountability of hospitals. Design research is causal design. The population of the research was all the employees of the hospital as much as 131. The technique of sampling using stratified random sampling of propotional method. The number of samples is the 91 employees. Technique of data analysis performed using multiple linear regression analysis with the method of hypothesis testing using t-test and F-test. Results of the study found that: 1) organizational culture affect performance significantly to hospital. The better the organizational culture which became a role model for employees in work will surely improve the performance of hospitals. 2) The influence of Organization Commitment significantly to hospital performance. The higher the commitment to reform in the works will improve the performance of hospitals. 3) Accountability influential significantly to hospital performance. The higher the accountability would enhance the performance of hospitals. That is, the better the shape of public accountability to the performance that has been done will be able to become the driving factor in improving the performance of hospitals.

\section{Abstrak}

Penelitian ini bertujuan untuk menganalisis: 1) Pengaruh budaya organisasi terhadap kinerja rumah sakit, 2) Pengaruh komitmen aparatur terhadap kinerja rumah sakit, 3) Pengaruh akuntabilitas terhadap kinerja rumah sakit. Desain penelitian ini adalah desain kausal. Populasi penelitian adalah seluruh pegawai Rumah sakit sebanyak 131 orang. Teknik pengambilan sampel menggunakan metode stratified propotional random sampling. Jumlah sampel adalah 91 orang pegawai. Teknik analisis data dilakukan dengan menggunakan analisis regresi linear berganda dengan kaedah pengujian hipotesis menggunakan uji $t$ dan uji F. Hasil penelitian menemukan bahwa : 1) Budaya organisasi berpengaruh signifikan terhadap kinerja rumah sakit. Semakin baik budaya organisasi yang menjadi panutan bagi pegawai dalam bekerja tentunya akan meningkatkan kinerja rumah sakit. 2) Komitmen aparatur berpengaruh signifikan terhadap kinerja rumah sakit. Semakin tinggi komitmen aparatur dalam bekerja akan meningkatkan kinerja rumah sakit. 3) Akuntabilitas berpengaruh signifikan terhadap kinerja rumah sakit. Semakin tinggi akuntabilitas tentunya akan meningkatkan kinerja rumah sakit. Artinya, semakin baik bentuk pertanggungjawaban kepada publik atas kinerja yang telah dilakukan akan dapat menjadi faktor pendorong dalam meningkatkan kinerja rumah sakit.
\end{abstract}

Key words : organizational culture, organization commitment, accountability, performance 


\section{INTRODUCTION}

In achieving the national objectives of the appropriate Preamble Indonesia 1945, namely protecting Nations Indonesia and all the spilled blood of Indonesia and to promote the general welfare, the intellectual life of the nation, and the world order carry out based on independence, social justice and lasting peace, then the health development geared to raising awareness, willingness, and ability to live a healthy life for everyone in order to increase the degree of extended public health can be realized.

Local governments have a very strategic role in efforts to accelerate public health degrees. Beside that, it also issued the decision letter of the Minister of health of the Republic of Indonesia number: 004/Menkes/Sk/I/2003 Decentralised policy and strategy health field, then this desentarlisasi success is required the commitment of local governments, legislatures, the public and other stakeholders on an ongoing basis health development in Indonesia.

These conditions encourage hospitals that used to cost centre, which all operational costs of HOSPITALS funded by the Central Government and local governments through NATIONAL and STATE BUDGET, now have to incorporate public service oriented orientation and profit oriented. It aims to be regional and central budget burden can be reduced or even if possible at the institution became one of the original sources of income-producing areas (PAD). It is therefore necessary that hospital management professionals towards the creation of a public institution oriented on value for money.

Organizational culture is the role model the behavior of the members of the Organization, so that if the organizational culture well, then member organizations will behave well in carrying out the work so as to support the improvement of organizational performance.

Commitment is the most fundamental thing for every person in any profession to cultivate. Without such a commitment, the tasks given to it is difficult to tackle. Then, the commitment to the organization is a situation where an employee's favor on a specific organization and its aims and intent on maintaining its membership in that organization. For civil servant (PNS) in the system of public administration of the Republic of Indonesia is the man of the State and of society, which set forth in Act No. 8 of 1974 regarding the subject of Staffing. In article 3, which reads: "civil servants are the elements of a State apparatus, the man of the State and of society with full fidelity and obedience to the Pancasila, the 1945 CONSTITUTION and the Government, organizes the tasks of governance and development.

The performance of the public organization of course also influenced by accountability. In the context of organisational, managerial accountability is the provision of information to the public and other constituencies that become stakeholders (stakeholders). Public accountability is also related to the obligation to explain and answer questions about what has been, is being and will be implemented in public organizations is planned. Therefore, the accountability of the Government should not only focus on the utilization of resources (inputs) only but also on performance.

Formulation of the problem in this research are:

1. the Sejauhmana influence of organizational culture on performance of hospitals?

2. the Sejauhmana influence of the commitment of the Government towards the performance of the hospital? 
3. the Sejauhmana influence on performance accountability of hospitals?

\section{METHODS}

\section{Research Design}

Based on the problems that will be discussed in this research, the design of the research is causal design. According to Umar (2009: 139) that the study design of causal research is useful to analyze the relations between one variable with another variable. The nature of those relationships that may occur between the variables examined are symmetrical, reciprocal and asimatris

\section{Population and Sample}

According to Bungin (2010: 99) is the entire research population (unisersum) of the object of research that can be a human, animal, vegetation, air, symptoms, symptom, event, events, value of life, attitude and so on so that this object can be a source of research data. Thus it is known that the population of the research subject or object is located in a region and qualified certain terms related to issues that are examined. The population of the research was the entire bottom of the PROVINCIAL HOSPITAL employees as many as 131 Basung.

Sampling techniques using the method of stratified random sampling, because the propotional population have diverse characteristics (heterogeneous) and Decker i.e. based on education level and esselon. With regard to determining the size of the sample used the formula Cochran (1991) in Umar (2009: 142) as follows:

$$
n o=\frac{t^{2} \cdot p \cdot q}{d^{2}}
$$

If the total sample is too large then the next correction formulas are used, namely:

$$
n=\frac{n o}{1+\frac{n o}{N}}
$$

Description

No $=$ number of samples

$\mathrm{n}=$ number of samples the corrected

$\mathrm{t}=$ the magnitude of $\mathrm{Z}$ correspond to the extent

significant $=5 \%$ i.e. $Z=1.96$

$\mathrm{p}=$ Magnitude proposi classification

$\mathrm{q}=1-\mathrm{p}$

$\mathrm{d}=$ amount of sample errors

estimated in this case is $5 \%$

$\mathrm{N}=$ size of populations examined $=$

$\mathrm{n}=$ sample size

There are three stages in a retrieval sampelnya, namely:

a. Identify the characteristics of the population

Based on characteristics that are found in the population then became strata in the study are:

(1) the educational level of Strata consisting of: Not Scholars (< S1) and Undergraduate ( $\geq \mathrm{S} 1)$

(2) the Strata comprising: under the III ( < III) and on the III (> III)

After strata is determined, the next step is to determine the proportion based on each of the strata and the results were as follows:

Number of population of 131 people

1) for educational level, proposinya are:

$$
\mathrm{S} 1 \mathrm{p} 1)<=108 / 131=0.82
$$$$
\geq \mathrm{S} 1(\mathrm{q} 1)=23 / 131=0.18
$$

2) for grade, its proportions are:

Grade III $<(\mathrm{p} 2)=36=0.27 / 131$

$\geq$ Grade III $(\mathrm{q} 2)=95 / 131=0.73$

b. determine the size of the sample

To determine the size of the sample used the formula Cochran (1991) in Umar (2009: 143) with the following results:

1. based on education level:

$$
\begin{aligned}
& n o=\frac{t^{2} \cdot p q}{d^{2}} \\
& n o=\frac{(1,96)^{2} \times 0,82 \times 0,18}{0,05^{2}} \\
& n o=226,72
\end{aligned}
$$




$$
\begin{aligned}
& \mathrm{n}=\frac{n_{o}}{1+\frac{n_{o}}{N}} \\
& \mathrm{n}=\frac{226,72}{1+\frac{226,72}{131}} \\
& \mathrm{n}=83,05
\end{aligned}
$$

2). Based on grade

$$
\begin{aligned}
& n o=\frac{(1,96)^{2} \times 0,27 \times 0,73}{0,05^{2}} \\
& n o=\frac{3,84 \times 0,1971}{0,0025} \\
& n o=302,76
\end{aligned}
$$

\section{Table 1 Sample Calculation Results}

\begin{tabular}{llllll}
\hline Num & Klasifikasi & P & Q & No & n \\
\hline 1 & Level of Education & 0,82 & 0,18 & 226,72 & 83,05 \\
\hline 2 & Grade & 0,27 & 0,73 & 302,76 & $91,47^{*}$ \\
\hline
\end{tabular}

Source: secondary data processing, 2013

Note : ${ }^{*}$ The selected number

From the results of the calculations carried out turned out to be the number of samples (n) the greatest number is located on the strata that is 91,47 (rounded to 91), then the number that's used to define the magnitude of the research sample. The percentage of the sample of the population i.e. $91 / 131 \times 100 \%=69,47 \%$. This figure

$$
\begin{aligned}
& \mathrm{n}=\frac{n_{o}}{1+\frac{n_{o}}{N}} \\
& \mathrm{n}=\frac{302,76}{1+\frac{302,76}{131}} \\
& \mathrm{n}=91,47
\end{aligned}
$$

Sample calculation results by using the formula of the correction formula and Cochran will be presented in the form of a table

Table 2. Sample Strata Based on Education Level and Grade

\begin{tabular}{lllll}
\hline \multirow{2}{*}{ Num } & \multirow{2}{*}{ Education Level } & Golongan & & \multirow{2}{*}{ Total } \\
\cline { 3 - 5 } & Y & III & $\geq$ III & \\
\hline 1 & Yet bachelor $(<\mathrm{S} 1)$ & 24 & 51 & 75 \\
2 & Already bachelor $(\geq \mathrm{S} 1)$ & 1 & 15 & 16 \\
\hline & Total & $\mathbf{2 5}$ & $\mathbf{6 6}$ & $\mathbf{9 1}$ \\
\hline
\end{tabular}

Source : secondary data processing, 2013

will be used as the basis for the determination of the sample.

a. Determine the subject

The calculation results obtained from a sample of 91 people to see in detail the distribution of number of samples can be seen in the table below.

As for the type and source of data used in this study are as follows:

1. primary Data, i.e. data obtained directly from the object of study, which includes data about the culture of the Organization, Government Commitment, accountability and performance of the hospital. This data is retrieved directly from the hospital employee by using a questionnaire research. 2. Secondary Data, i.e. data that support the study results, which includes an overview of the research object, number of employees, 
and other data that can enrich the results of research. This secondary data obtained from third parties

2. Operational Defenisi

Operating Defenisi each of the variables of this study are as follows:

1. the performance of the Hospital (Y)

The performance of the hospital is on the research achievement of level overview of implementation of the activity/program/policy in realizing the goal, purpose, mission and vision of the hospital. Indicators of hospital performance on this research is (Mahmudi, 2007: 97):
a) Input
b) Output
c) Outcomes
d) Benefit
e) Impact

2. organizational culture (X 1)

Organizational culture is in this research are values or rules in the Organization of hospitals and embraced by all employees in carrying out the task. Indicator variable organizational culture on this research is (Robbins, 2006: 305):
a. innovation and risk taking
b. attention to detail
c. Results Orientation
d. orientation of people
e. Orientation team
f. Keagresifan

\section{g. Stability}

3. the commitment of the organization (x 2)

Commitment of the apparatus referred to in this research is a tendency in myself to feel active employees with a full sense of responsibility and conscientious in carrying out the work. Indicator of commitment in this study among others (Allen and Meyer, 1993 in Robins, 2006: 204):

a. affective Commitment

b. normative Commitment

c. ongoing Commitment

4. Accountability (X 3)
Accountability is in this research is a form of accountability for the hospital to the public for his performance has done. Indicator accountability on this research is (Mardiasmo, 2001: 50):

a. legal Accountability and honesty

b. Accountability process

c. Akuntabilita program

d. Accountability policy

2. Data Analysis Techniques

Data analysis techniques to test the hypothesis of linear multiple regression study is by means of hypothesis testing using t-test and F-test.

\section{RESULT}

Descriptive Variable Analysis Of Research Results

1. Description of the Performance Variables The performance is on the research achievement of level overview of implementation of the activity/program/policy in realizing the goal, purpose, mission and vision of the hospital. On output indicators,

As much as $22.42 \%$ of employees stated always that good hospital performance output, often stated, $\%$ 51,65 19,78\% stated sometimes, $5,49 \%$ said rarely, and as much as $0.66 \%$ said never. Average score indicator input is close to the level of respondents 3.90 (TCR) of $77,93 \%$. This value indicates that the output indicators are at a sufficient criterion. Thus it can be said that the output performance of the hospitals are still not optimally. Output performance of the hospital are categorized simply as output from the use of the budget is the quantity or the quality has not been quantified to the maximum, the output of the programs and activities that are planned and implemented with less work from the programs and activities carried out less meet the kreteria.

On learning outcomes, indicators as much as $31,87 \%$ hospital employee stated always that 
learning outcomes of hospital performance good, $33,52 \%$ stated often, $25,27 \%$ stated sometimes, area of $7.69 \%$ said rarely, and as much as $1.65 \%$ said never. The average score is an indicator of learning outcomes is close to the level of 3,86 respondents (TCR) of $77,25 \%$. The value of this indicator shows that learning outcomes are at a sufficient criterion. Thus it can be said that the learning outcomes of hospital performance is still not up. Relatively good performance of hospitals learning outcomes for all program activities and outputs is still less could be used and exploited by society as a maximum

On indicators of benefit, as much as $28,98 \%$ hospital employee stated always that benefit both hospital performance, $43,59 \%$ stated often, $15.75 \%$ stated sometimes, $9,89 \%$ said rarely, and as much as 1,83\% said never. The average score is an indicator of learning outcomes is the level is nothing about four of the respondents (TCR) of $77,58 \%$. This value indicates that the indicator of benefit is enough criteria. Thus it can be said that the benefit performance of the hospitals are still not optimally.

On indicators of impact, as much as a hospital clerk $31,87 \%$ stated always that impact the performance of a good hospital, often stated, $29,67 \% \quad 29.30 \%$ States sometimes, $+5.86 \%$ claimed rarely, and as much as $3.30 \%$ said never. The average score is an indicator of learning outcomes is the height to the level close to the respondent (TCR) of $76,19 \%$. This value indicates that the impact indicators are at a sufficient criterion. Thus it can be said that the impact of hospital performance is still not up.

1. organizational culture

Organizational culture is in this research are values or rules in the Organization of hospitals and embraced by all employees in carrying out the task. From the results of the study revealed that as much as $23,37 \%$ said always, often stated,\% 39,19 20,61\% stated sometimes, $14,41 \%$ declared rare and $2.42 \%$ said never. Judging from the average score variable organizational culture is 3.67 with a level of attainment of respondents answer $73,33 \%$. This indicates that the organizational culture at the hospital are on a category is enough. These results indicate that employees follow and practise the values or the regulations.

On the indicators of innovation and risk taking, as much of $21,79 \%$ hospital employee stated always innovating and daring do risk-taking in work, $41,58 \%$ stated often, $17.77 \%$ stated sometimes, $16.30 \%$ said rarely, and as much as $2.56 \%$ said never. The average score is an indicator of innovation and risk taking is close to the level of 3,64 respondents (TCR) of 72,75\%. This value indicates that an indicator of innovation and risk taking are at a sufficient criterion. Thus it can be said that innovation and risk-taking by employees working in hospitals are still not optimally.

At attention indicators as much as $24,18 \%$ hospital employee stated always do kerincian attention in working, $36.04 \%$ stated often, $23.96 \%$ stated sometimes, $13,41 \%$ said rarely, and as much as $2.42 \%$ said never. The average score is an indicator of the attention kerincian is close to the level of 3,66 respondents (TCR) of 73,23\%. This value indicates that the indicator is in the kerincian attention

The criteria is sufficient. Thus it can be said that the attention committed by an employee in the work still hasn't been fullest.

On the orientation of the indicator results, a total of $24,18 \%$ hospital employee stated always do the orientation results in works, often stated, $\% \quad 37,31 \quad 21,37 \%$ expresses sometimes, $14,62 \%$ declared rare, and as much as $2.53 \%$ said never. Average score 
indicator results orientation is a product with a level of 3,66 respondents (TCR) of $73,20 \%$. This value indicates that the results orientation indicators are at a sufficient criterion. Thus it can be said that the results orientation conducted by the employees working in the hospital are still not optimally.

On the orientation of the indicator, as much as a hospital clerk $24,18 \%$ stated always do the orientation of people in work, the asserts $37,31 \% 21,37 \%$ expresses often, sometimes, rarely, stated $14,62 \%$ and as much as $2.53 \%$ said never. The average score is an indicator of the orientation of the person is close to the level of 3,66 respondents (TCR) of $73,20 \%$. This value specifies that the orientation indicator on the criteria people are enough. Thus it can be said that the orientation of the people perpetrated by employees working in hospitals are still not optimally

Orientation indicator on the team, as much as $24,18 \%$ hospital employee stated always do in work team orientation, $37,31 \%$ stated often, $21,37 \%$ expresses sometimes, $14,62 \%$ declared rare, and as much as $2.53 \%$ said never. Average score indicator orientation team is close to the level of 3,66 respondents (TCR) of $73,20 \%$. This value indicates that teams are on orientation indicator criteria fairly. Thus it can be said that the orientation of the team that performed by employees working in hospitals are still not optimally.

On the indicator work, as many as keagresifan 24,18\% hospital employee stated always has keagresifan in work, often stated,\% $\quad 37,31 \quad 21,37 \% \quad$ expresses sometimes, $14,62 \%$ declared rare, and as much as $2.53 \%$ said never. An average score of indicators keagresifan work is close to the level of 3,66 respondents (TCR) of 73,20\%. This value indicates that the indicator keagresifan is enough criteria work. Thus it can be said that the hospital employee working keagresifan in the works is still not up.

On the indicator work, stability or stability as much as $24,18 \%$ hospital officials declared the steadiness or stability always has work in carrying out the task, often stated, $\% \quad 37,31 \quad 21,37 \%$ expresses sometimes, $14,62 \%$ declared rare, and as much as $2.53 \%$ said never. Average score indicator steadiness or stability of employment is close to the level of 3,66 respondents (TCR) of $73,20 \%$. This value indicates that the job stability or stability indicator is on enough criteria. Thus it can be said that the steadiness or stability of employment employees working in hospitals are still not optimally

1. commitment of the Organization

Commitment of the organization referred to in this research is a tendency within hospital employees to be active with a full sense of responsibility and conscientious in carrying out the work. $43,23 \%$ of employees stated always have a commitment in the work, the asserts frequently, 33,23\% $15,28 \%$ stated sometimes, $7.64 \%$ claimed rarely and $0,62 \%$ said never. Judging from the average score variables organization commitment is 4.11 with the level of achievement of the answers of the respondents amounted to $82,16 \%$. This indicates that the commitment to reform the hospital are on a category either. These results indicate that the employee of the hospital has a high commitment in carrying out the task.

On the affective commitment, as much an indicator of $35,01 \%$ hospital employee stated, affective commitment always had $32,65 \%$ stated often, $20,57 \%$ stated sometimes, $10,83 \%$ said rarely, and as much as $0.94 \%$ said never. An average score of affective commitment indicator is close to the level of respondents 3.90 (TCR) of 
$77,99 \%$. This value indicates that the indicator is affective commitment criteria is sufficient. Thus it can be said that hospital employees affective commitment is still not up.

On the normative commitments, indicators as much as $52.38 \%$ hospital employee stated always had normative, $37,18 \%$ stated often, $6.41 \%$ stated sometimes, $3.85 \%$ said rarely, and as much as $0.18 \%$ said never. An average score of normative indicators are close to the level of 4.38 respondents (TCR) of $87,55 \%$. This value indicates that the normative indicators are at a sufficient criterion. Thus it can be said that the hospital employee normative still not optimally.

Continuous commitment on the indicator, as many as $42,31 \%$ Hospital officials declared ongoing, always has stated often, $29,85 \% \quad 18,86 \%$ stated sometimes, $8,24 \%$ said rarely, and as much as $0.73 \%$ said never. The average score is an indicator of sustainability is close to the level of respondents 4.05 (TCR) of $80,95 \%$. This value indicates that the indicator of sustainability criteria is sufficient. Thus it can be said that the sustainability of hospital employees are still not optimally.

\section{Accountability}

Accountability is in this research is a form of accountability to the public hospital for his performance has done. Data analysis the results obtained that information as much as $32,28 \%$ employees that the hospital always have accountability, $35.31 \%$ were either $18,58 \%$ said often, sometimes, rarely stated as $12,28 \%$ and as much as $1,57 \%$ officials said never. Judging from the average score is 3.84 accountability with variable levels of attainment of respondents answer $76,89 \%$. This variable indicates that accountability is on the category is sufficient.
These results indicate that the level of accountability of the hospital is still not up.

Accountability indicators on honesty and accountability law, as much as $31,99 \%$ hospital employee stated that the hospital always has honesty and accountability accountability $37,61 \%$, stated the law often, $18.44 \%$ stated sometimes, $10,74 \%$ declared rare, and as much as $1.22 \%$ said never. An average score of honesty and accountability indicators legal accountability is about four close to the level of respondents (TCR) of $77,68 \%$. This value indicates that the honesty and accountability indicators of legal accountability is sufficient criteria. Thus it can be said that the legal accountability of honesty and accountability in the hospital are still not optimally.

On the indicators of accountability processes, as much as $33,58 \%$ hospital employee stated that the hospital always have accountability process, $34,55 \%$ stated often, $17,58 \%$ stated sometimes, $12,82 \%$ declared rare, and as much as $+1.47 \%$ said never. The average score is an indicator of the accountability process is close to the level of 3,86 respondents (TCR) of 77,19\%. This value indicates that the accountability process indicators are at a sufficient criterion. Thus it can be said that the accountability process in the hospital are still not optimally.

On indicators of accountability program, as many as $31,88 \%$ of the employees of the hospital said that the hospital always have accountability program, 38,29\% said often, $16.75 \%$ stated sometimes, $12,13 \%$ said rarely, and as much as $0.94 \%$ said never. Average score indicator accountability program is about four close to the level of respondents (TCR) of $77,61 \%$. This value indicates that the program is on the accountability indicators criteria are sufficient. Thus it can be said that accountability programs at hospitals are still not optimally. 
On indicators of accountability policy, as much as $31,65 \%$ hospital employee stated that the hospital always have accountability policy, $30,77 \%$ stated often, $21,54 \%$ stated sometimes, $13,41 \%$ said rarely, and as much as $2.64 \%$ said never. Average score indicator accountability policy is 3.75 with a level close to the respondent (TCR) of $76,89 \%$. This value indicates that the indicators of accountability accountability is sufficient criteria policy

Thus it can be said that accountability accountability policies on hospitals are still not optimally.

\section{B. Results Of Hypothesis Testing}

Hypothesis testing is carried out to analyze the influence of the culture of the Organization, government commitment and accountability towards the performance of hospitals.

1. F-test

The F-test is used to see the influence of the free variables of variables are bound together. The results of data analysis for test-F can be seen in the following table:

Table 3

ANOVA $^{b}$

\begin{tabular}{|c|c|c|c|c|c|c|}
\hline Model & & $\begin{array}{l}\text { Sum of } \\
\text { Squares }\end{array}$ & $\mathrm{df}$ & Mean Square & $\mathrm{F}$ & Sig. \\
\hline \multirow[t]{3}{*}{1} & Regression & 4290.725 & 3 & 1430.242 & 21.252 & $.000^{\mathrm{a}}$ \\
\hline & Residual & 5855.100 & 87 & 67.300 & & \\
\hline & Total & 10145.824 & 90 & & & \\
\hline
\end{tabular}

a. Predictors: (Constant), Akuntabilitas, Budaya Organisasi, Komitmen Aparatur

b. Dependent Variable: Kinerja

Based on the test $\mathrm{F}$ it is known that the value $F$ calculate the significance value of $21,2520.000$. If the value of significance compared to the alpha () then it is evident that the value of smaller significance of alpha $(0.00<0.05)$. This means simultaneously variable culture of the Organization, government commitment and accountability impact significantly to hospital performance.

\section{Test t}

The t-test is used to see the influence of the free variables of variables are bound is partial. As for the results of the analysis of the influence of the culture of the Organization, government commitment and accountability towards partial hospital performance is as follows:

\section{Table 4 The t-test results}

\begin{tabular}{|c|c|c|c|c|}
\hline Num & Variabel & $\begin{array}{l}\text { Coeficient } \\
\text { Regression }\end{array}$ & of Sig & Conclussion \\
\hline 1 & $\begin{array}{l}\text { Organization } \\
\text { Culture }\left(\mathrm{X}_{1}\right)\end{array}$ & 0,119 & 0,046 & Significant \\
\hline 2 & $\begin{array}{l}\text { Organization } \\
\text { Commitment }\left(\mathrm{X}_{2}\right)\end{array}$ & 0,263 & 0,040 & Significant \\
\hline 3 & $\begin{array}{l}\text { Accountability } \\
\text { (X3) }\end{array}$ & 0,154 & 0,016 & Significant \\
\hline
\end{tabular}

Source: primary data Processing, 2013 
Based on the data shown in table 4 can be done partially test each variable as follows:

a. the coefficient of regression the influence of organizational culture on performance of hospitals is 0,119 , with the significance of 0.046. If the value of significance compared to the alpha $(=0.05)$ then it is evident that the value of smaller significance of alpha $(0.046<0.05)$. Thus it can be said that the organizational culture affect performance significantly to hospital

b. the coefficient of regression commitment against hospital performance is of significance to the value of $0,2630,040$. If the value of significance compared to the alpha $(=0.05)$ then it is evident that the value of smaller significance of alpha $(0,040$ $<0.050$ ). Thus it can be said that the commitment of a significant effect on the performance of the apparatus of the hospital.

c. the regression Coefficient of performance accountability of hospitals is 0,154 with the value significance of 0,016 . If the value of significance compared to the alpha $(=0.05)$ then it is evident that the value of smaller significance of alpha $(0,016<0.05)$. Thus it can be said that a significant effect on performance accountability of hospitals

Summaries of the data analysis :

1. the influence of organizational culture on performance of hospitals

Based on the test results the first hypothesis in mind that organizational culture affect performance significantly to hospital. The better the organizational culture which became a role model for employees in work will surely improve the performance of hospitals. That is when employees have a culture in the work of innovation and daring have resolving risks, attention to detail, oriented towards the results/person/team and have a keagresifan in the works and has a stability in the works of course will support the hospital's success in the achievement of organizational performance.

These research findings prove the performance of hospital performance is influenced by organizational culture organizational culture is a role model because of the behavior of the members of the Organization, so that if the organizational culture well, then member organizations will behave well in carrying out the work so as to support improved performance against the hospital.

The findings of this research is supported by the opinion of Djokosantoso (2005: 89) stating that the existence of the interconnectedness of the relationship between organizational culture and organizational performance can be explained that the better the quality factors in organizational culture increasingly good performance of the organization.

2.The influence of the Organization Commitment On the Hospital Performance

Based on the results of the second hypothesis testing revealed that influential organization commitment significantly to hospital performance. The higher the commitment to reform in the works will improve the performance of hospitals. Meaning that when employees feel fully active with a high sense of responsibility and conscientious in carrying out the work will certainly be able to encourage improved performance of hospitals.

From the results of these research findings can be confirmed that the commitment of the organization is the most fundamental thing for every person in any profession to cultivate. Without such a 
commitment, the tasks given to it is difficult to tackle. Then, the commitment to the organization is a situation where an employee's favor on a specific organization and its aims and intent on maintaining its membership in that organization.

The findings of this research is supported by the opinion of Robbins (2006: 285) who suggested that the commitment of the employees in an organization is one that reflects the attitude of feeling like or do not like an employee of the organization where he works. Organizational commitment demonstrates accountability from someone in identifying his involvement in an organization. With a sense of having participated, then incurred a liability to perform their obligations properly anyway, so it can be concluded that organizational commitment affect organizational performance

3. influence of Accountability with respect to the performance of the hospital.

Based on the results of the third hypothesis testing revealed that a significant effect on performance accountability of hospitals. The higher the accountability would enhance the performance of hospitals. That is, the better the shape of the hospital to the public accountability of the performance that has been done will be able to become the driving factor in improving the performance of the hospital for the foreseeable future.

The findings of this research show that the performance of the hospital affected by the accountability because in the context of organisational, managerial accountability is the provision of information to the public and other constituents to be stakeholders (stakeholders). Public accountability is also related to the obligation to explain and answer questions about what has been, is being and will be implemented in public organizations is planned. Therefore, the accountability of the Government should not only focus on the utilization of resources (inputs) only but also on performance.

In the autonomous region of discourse, public accountability is the key word. He demands public accountability because the public wants the Government as trustee responsible for establishing performance he has done would be obliged to manage Community funds in order to run his Government. To support the Fund management community by doing good then the management of the hospital should give priority to the interests of the community a lot.

The findings of this research is supported by the opinion of Mahsun and Heribert (2006: 97) managerial accountability in public organizations will encourage the achievement of organizational performance are becoming more effective. When a public organization managerial accountability can manifest will contribute positively to the achievement of the vision and mission of the organization which in turn will improve the performance of public organizations.

\section{CONCLUSSION}

From the results of the research and the discussion in the previous chapter do on the conclusion can be drawn that the organizational culture affect performance significantly to hospital. The better the organizational culture which became a role model for employees in work will surely improve the performance of hospitals. That is when employees have a culture in the work of innovation and daring have resolving risks, attention to detail, oriented towards the results/person/team and have a keagresifan in the works and has a solidity in course work will support the hospital's 
success in the achievement of organizational performance.

The commitment of significant impact on the performance of the organization of the hospital. The higher the commitment to reform in the works will improve the performance of hospitals. Meaning that when employees feel fully active with a high sense of responsibility and conscientious in carrying out the work will certainly be pushing the improvement the performance of hospitals.

Significant effect on performance accountability of hospitals. The higher the accountability would enhance the performance of hospitals. That is, the better the shape of the hospital to the public accountability of the performance that has been done will be able to become the driving factor in improving the performance of the hospital for the foreseeable future.

\section{a. Policy implications}

Of research results, discussions and conclusions that have been described above, some things can be recommended as a policy is to improve the performance of the hospital for the foreseeable future then things need to be done as follows:

1. Hospital organizational performance in order to be truly useful as expected then it needs to be applied to the control of management. This is due to the importance of the role of the hospital management to work whether or not the hospital. In addition to the reward and increase the quality of human resources leads to increased kesesjahteraan and position of the parties involved in the hospital. An equally important factor is the application of punishment that acts as a counterbalance. Increased knowledge and expertise, and increase the availability of facilities and infrastructure as well as integrated management control will be able to improve the performance of hospital organization.

2. Policy on the cultural aspects of the Organization, to do the following things:

a. Employees must learn the methods and procedures for the execution of the job on a daily basis in order to work effectively and efficiently

b. the Clerk shall perform the duties and functions in accordance with the applicable standard

c. Clerks need to do the latest innovations in carrying out the work

d. Employees should attempt to reach the targets of the implementation of the work

e. Employees should get the job done quickly and right on target

3. Policies on aspects of the reform commitments, needs to be done the following things:

a. Employees should aspire to spend his career in public hospitals Lubuk Basung Employees should feel part of the hospital

b. Employees should have a high loyalty to the hospital

4. The Policy on accountability, to do the following things:

a. Policy established with emphasis on public interest

b. Community should be able to perform the assessment and surveillance policies takento hospital c. hospitals need to consider programs that maximum results with minimal cost 


\section{REFERENCES}

10.22202/economica.2015.v4.i1.267

Bungin, M. Burhan (2010), Metodologi Penelitian Kuantitaif : Komunikasi, Ekonomi dan Kebijakan Publik Serta Ilmu-Ilmu Sosial Lainnya. Jakarta : Kencana

Djokosantoso, Moeljono, 2005. Good Corporate Culture sebagai Inti dari Good Corporate Governance. Jakarta: PT. Elex Media Komputido
Mahmudi. 2007. Manajemen Kinerja Sektor Publik. Edisis Revisi. Yogyakarta: UPP AMP YKPN.

Mahsun, Mohamad, Firma. S, dan Heribertus. 2006. Akuntansi Sektor Publik. Ed 1. Yogyakarta: BPFEYogyakarta

Robbins, Stephen. 2006. Perilaku Organisasi. Alih bahasa : Tim Indeks. Jakarta : PT. INDEKS Kelompom Gramedia

Umar, Husein. 2009. Metode Penelitian Untuk Skripsi dan Tesis Bisnis. Jakarta: PT Raja Grafindo Persada 